\title{
Pinching effects on growth and yield of okra
}

\author{
Abid Ali ${ }^{1}$, Ghulam $\mathrm{Nabi}^{1}$, Muhammad Irshad ${ }^{1}$, Muhammad Noman Khan \\ $1^{*}$, Muhammad Israr ${ }^{2}$, Shamsher Ali ${ }^{3}$, Javed Rehman ${ }^{4}$ and Waqas Ali ${ }^{1}$ \\ 1. Department of Horticulture, The University of Agriculture Peshawar, Pakistan \\ 2. Department of Rural development, The University of Agriculture Peshawar, Pakistan \\ 3. Department of Soil and Environmental Sciences, The University of Agriculture Peshawar, Pakistan \\ 4. Agriculture Research Institute Mingora, Swat, Pakistan \\ *Corresponding author's email: nomanhort@aup.edu.pk
}

Citation

Abid Ali, Ghulam Nabi, Muhammad Irshad, Muhammad Noman Khan, Muhammad Israr, Shamsher Ali, Javed Rehman and Waqas Ali. Pinching effects on growth and yield of okra. Pure and Applied Biology. Vol. 11, Issue 1, pp135-145. http://dx.doi.org/10.19045/bspab.2022.110015

\begin{tabular}{llll}
\hline Received: 16/02/2021 & Revised: 23/04/2021 & Accepted: 28/04/2021 & Online First: 21/05/2021 \\
\hline
\end{tabular}

\section{Abstract}

An experiment "Effect of different pinching stages on growth and yield of okra varieties" under agro climatic conditions of Dargai Malakand was conducted during April-November 2019.The experiment was carried out according to Randomised Complete Block Design (RCBD) with split plot arrangements, and was replicated three times. Four varieties (Arka Anamica, Sabz Pari, Swat Green, and Salva Hybrid) were allotted to main plots and four pinching stages (no pinching, pinching at $1^{\text {st }}, 2^{\text {nd }}$ and $3^{\text {rd }}$ node stage) were allotted to sub plots. In this study, pinching practice significantly affected different growth and yield parameters of tested okra varieties. Among the pinching stages, plants pinched at $3^{\text {rd }}$ node stage produced maximum number of lateral branches plant $^{-1}$ (8.15), number of leaves plant ${ }^{-1}$ (176.75), number of pods plant ${ }^{-1}$ (15.53) yield plot $^{-1}(2.32$ $\mathrm{kg}$ ), yield ha-1 (19.39 tons). Whereas, minimum number of days to flowering (47.25) was recorded by un-pinched plants. Furthermore, among tested varieties, Swat Green pinched at $3^{\text {rd }}$ node stage produced more number of lateral branches plant ${ }^{-1}$ (8.99), number of leaves plant ${ }^{-1}$ (189.5) number of pods plant ${ }^{-1}$ (15.17), number of pickings (23.08), pod length $(12.37 \mathrm{~cm})$, individual pod weight $(15.20 \mathrm{~g})$, yield $\operatorname{plot}^{-1}(2.30 \mathrm{~kg})$ and yield ha ${ }^{-1}(19.22 \mathrm{tons})$. These results revealed that pinching treatment at $3^{\text {rd }}$ node stage is beneficial to improve growth and yield traits of tested okra varieties particularly of Swat Green.

Keywords: Pinching stages; Growth and yield; Okra cultivars

\section{Introduction}

Okra (Abelmoschus esculentus L.) is a vegetable crop grown in subtropical, tropical and Mediterranean countries. Okra belongs to family Malvacea. Okra is grown commercially in different parts of the world and can be consumed both in fresh and in dried form [1] Okra is a perennial and herbaceous vegetable but is treated as annual.
Its cultivation is done for its fruits which can be consumed in fresh, cooked, dried, or in processed form. It is best source of proteins, fibers, vitamins and essential minerals and has more nutritious value in comparison to tomato and eggplant. Okra fruit is rich source of carbohydrates and other micronutrienst, $100 \mathrm{~g}$ of okra fruit may contains $11.30 \mathrm{mg}$ carbohydrate, $4.40 \mathrm{mg}$ protein, $0.6 \mathrm{mg}$ fat, 2.1 
mg fibres, 532. $\mathrm{mg} \mathrm{Ca}, 0.70 \mathrm{mg} \mathrm{Fe}, 0.25 \mathrm{mg}$ thiamine and $2.8 \mathrm{mg}$ of riboflavin [2] Moreover, in okra seeds (20\%) of Protein and $(40 \%)$ of oil contents are reported which could be an alternative edible oil source [3] The species are perennial, mostly cultivated as an annual, the plant grows up to 2 meters high, and the leaves are about 10 to $20 \mathrm{~cm}$ long and broad and contain about 5 to 7 lobes. The flower is hermaphrodite in nature, 4 to 8 $\mathrm{cm}$ in diameter and composed of five yellowish petals with red or yellow spot at the bottom. The pod of okra is about $18 \mathrm{~cm}$ long containing many seeds [4]

Okra is thought to be originated from the South Asia i-e, Burmuda, India and Pakistan [5] and in Africa and is the utmost lifesustaining vegetable grown in all tropical zones. Okra is cultivated on larger scale for commercial purpose and also as a garden vegetable [6]

Okra is economical and important vegetable crop grown for its green pods and is cultivated in summer in tropical region of the world [7] It is one of the most heat and drought resistant specie in vegetables and can tolerate soils with heavy clay. Okra can be grown in almost all types of soil but field with better drainage system and good organic fertilizer is suitable for okra cultivation. Optimum range of $\mathrm{pH}$ for Okra is 6.6 to 8.0. Seed germination is best in temperature ranging from $20-25{ }^{\circ} \mathrm{C}$. There is almost no emergence when temperature is less than $16^{\circ} \mathrm{C}$. The optimum temperature for okra cultivation is between $25{ }^{\circ} \mathrm{C}$ and $30{ }^{\circ} \mathrm{C}$ [8].

The soil and climate of Pakistan is suitable for the cultivation of okra crop. However, its production is not as economical as in other countries of the world [9]. India is the leading country in okra production with $70 \%$ world total production, followed by Nigeria $15 \%$, Egypt 17\%, whereas Pakistan contributing $2 \%$ to world okra production [10]. According to statistics, in Pakistan okra was cultivated on about 14855 hectares area from which
112983 tones production was received. While in Khyber Pakhtunkhwa Okra crop was cultivated on 1957 hectare area with the production of 15630 tons. Whereas, in Pakistan the average yield of green okra pods is about 8-10 tons ha $^{-1}$, which is very less as compare to developed countries which is about 30 tons ha ${ }^{-1}$ [11]. Cultural practices play vital role to enhance the growth and yield of vegetable crops. Plant regulators and fertilizers are not environment friendly, therefore agriculturists are trying to adopt environment friendly techniques to improve the yield of vegetable crops. Pinching is a cultural practice in which terminal portion of stem is cut down to enhance the literal branches. This technique is commonly used in cucurbits as well as in some okra cultivars in other countries. Keeping in view the importance of pinching in vegetable crops the current study was carried out with the objective to optimize proper stage of pinching for optimal growth and yield of okra, To evaluate the okra variety in which pinching is most effective, and to find out the interactive effect of pinching and varieties on okra growth and yield.

\section{Materials and Methods}

An experiment with title "Effect of different pinching stages on growth and yield of okra varieties" was carried out in year 2019 at Jabban Agriculture Extension Department Dargai Malakand. The key objective of the experiment was to evaluate the effect of pinching on growth as well as yield of okra (Abelmoschusb esculentus L.)

\section{Land preparation}

Land selected for trial was thoroughly ploughed and levelled; seeds imbedded overnight in water were sown on ridges. The plant to plant distance $20 \mathrm{~cm}$ and row to row distance $60 \mathrm{~cm}$ was maintained. Farm Yard manures at the rate of 30 tons ha ${ }^{-1}$ was added at the time of field preparation. At the rate of 120- 90- $60 \mathrm{~kg} \mathrm{ha}^{-1}$ nitrogen, phosphorus and potash was applied to the field as suggested 
by [12]. All K, P, and half $\mathrm{N}$ was added during sowing time, whereas during earthing up the remained half $\mathrm{N}$ was added [12]. The other crop protection and cultural practices was carried out whenever needed.

Seed source, sowing and pinching of plants The seeds of okra (local and Hybrid varieties) were purchased from a reliable retailer in Peshawar. Sixteen (16) treatment combinations were made, five seeds/treatment were sowed with a total of 80 seeds (16 treatments combinations x 5 seeds) were sowed in single Replication. The $1^{\text {st }}, 2^{\text {nd }}$ and $3^{\text {rd }}$ node were pinched (heading back the terminal growth with the help of fingers manually) of its vegetative growth.

Un-pinched plants $=$ no pinching was carried out (control)

$1^{\text {st }}$ node $=$ the seedling was pinched out at first node stage.

$2^{\text {nd }}$ node $=$ the seedling terminal was pinched out at two node growth stage.

$3^{\text {rd }}$ node $=$ the seedling was pinched at tree node growth stage.

\section{Experimental design}

The trail was carried out according to the Randomized Complete Block Design (RCBD) with split plot arrangement. Varieties (Factor A) were allotted to main plots, while pinching levels (Factor B) were allotted to sub plots. Twelve treatments of various interactions were there, and replication of each treatment was three times in order to reduce the experimental error and get accurate result. The size of each plot was $1.2 \mathrm{~m}^{2}(0.6 \times 2 \mathrm{~m})$ and there was 4 rows and each row were 2 meters long. The row- row distance was $60 \mathrm{~cm}$ while plant- plant distance was maintained $20 \mathrm{~cm}$, distance between plot to plot was $60 \mathrm{~cm}$ and total area of experiment was $(12 \times 6 \mathrm{~m})=72 \mathrm{~m}^{2}$. Five seeds were sown in each row and seed to seed distance was $20 \mathrm{~cm}$.

\section{Studied parameters}

The parameters which were studied for finding out the effect of pinching on okra growth and yield are as under.

Number of lateral branches plant ${ }^{-1}$

In each treatment numbers of branches of four selected plants were counted and their average was recorded.

\section{Number of leaves plant ${ }^{-1}$}

In each treatment in selected plants numbers of leaves were counted and their average was calculated.

\section{Number of Days to flowering}

From the date of sowing days to flowering was counted until first flower appears in each plot and their average was recorded.

\section{Number of pickings}

In each plot the number of picking was recorded, and mean was calculated.

\section{Pods plant ${ }^{-1}$}

Number of pods of selected plants in each plot were counted and their average was recorded.

\section{Individual pod weight (g)}

Individual pod weight of randomly selected pods in each treatment was measured by electrical balance and their mean was calculated.

\section{Pod length $(\mathrm{cm})$}

The length of selected pods in every treatment were measured through measuring tape and mean was calculated.

\section{Pod diameter (mm):}

With the help of Vernier caliper the diameter of the pod was measured. In each plot six plants were randomly selected, then diameter of selected pods was measured, and their average was recorded.

\section{Plant height $(\mathbf{c m})$}

In each plot five plants were randomly selected; their height was measured, and average was calculated. 


\section{Weight of fruits plot $^{-1}$ ( kg)}

The following formula was used for the calculation of weight of fruits per plot.

Weight of fruits plot $^{-1}=$ Total pickings pods weight $(\mathrm{kg})$

Yield ha-1 (tons)

$$
\text { Plot area }\left(\mathrm{m}^{2}\right)
$$

The following formula was used for calculating yield ha-1 (tons).

$$
\text { Yield ha }{ }^{-1}=\frac{\text { Sum of all picking weight } \times 10000\left(\mathrm{~m}^{2}\right)}{\text { Plot area }\left(\mathrm{m}^{2}\right)}
$$

\section{Statistical analysis}

Statistic-8.1 version software was used for statistical analysis of the data, and differences between treatments means were determined by using the LSD test at 0.05 probability.

\section{Results and discussion}

The research work "Effect of different pinching stages on growth and yield of okra varieties" was carried out at Jabban Agriculture Extension Department Dargai Malakand during 2019. The results of various experimental data were compared and statistically analysed. Analysis of variance (ANOVA) and mean tables are given for presenting the results regarding number of lateral branches plant ${ }^{-1}$, length of lateral branches $(\mathrm{cm})$, number of days to flowering, number of leaves plant ${ }^{-1}$, number of pickings, weight of fruits picking ${ }^{-1}$ plot $^{-1}(\mathrm{~kg})$, individual pod weight $(\mathrm{g})$, pod length $(\mathrm{cm})$, pod diameter $(\mathrm{mm})$, pods plant ${ }^{-1}$, yield ha ${ }^{-1}$ (tons) of okra (Abelmoschus esculents L.).

Number of lateral branches plant ${ }^{-1}$.

The mean values for number of lateral branches plant ${ }^{-1}$ are given in table-1. Mean table indicates that different pinching stages showed significant effect on number of lateral branches plant ${ }^{-1}$ in all tested varieties, while their interaction was found nonsignificant. According to means for different pinching stages, more number of lateral branches per plant (8.15) was found in plants pinched at $3^{\text {rd }}$ node stage, followed by $2^{\text {nd }}$ node stage (8.05), while minimum number of lateral branches plant ${ }^{-1}$ (6.67) was found in un-pinched plants. Similar to our results [13] observed more number of lateral branches in Butternuts plants pinched at $3^{\text {rd }}$ node stage.

Regarding okra varieties, a greater number of lateral branches plant ${ }^{-1}$ (8.99) was found in Swat Green followed by Sabz Pari (7.62), while a smaller number of lateral branches plant $^{-1}$ (6.59) was observed in Salwa Hybrid variety.

By removing the apical part from main branches, auxiliary buds become free from correlative suppression of apical dominance thus redirected plant metabolites from vertical growth to horizontal growth, thus due to translocation of photosynthates and hormones to leaf axils the number of lateral branches increases [13]. Like our results, increase in number of lateral branches as a result of pinching treatment has been reported in various vegetables species including Chickpea [14], Fenugreek [3], Bottle gourd [15] and in Field bean [16].

Number of leaves plant ${ }^{-1}$

The mean values for number of leaves plant ${ }^{-}$ ${ }^{1}$ are given in table-1 Mean table indicates that different pinching stages showed significant effect on number of leaves plant ${ }^{-1}$ in all tested varieties while their interaction was found non-significant.

According to means for different pinching stages, more number of leaves plant ${ }^{-1}$ (176.75) was found in plants pinched at $3^{\text {rd }}$ node stage, followed by plants pinched at $2^{\text {nd }}$ node stage (170.25), while minimum number of leaves plant ${ }^{-1}$ (130.50) was found in unpinched plants. Regarding okra varieties, a greater number of leaves plant ${ }^{-1}$ (189.50) was found in Swat Green, followed by Salwa 
Hybrid (159.75), while a smaller number of leaves plant ${ }^{-1}$ (141.00) was observed in Sabz Pari variety. The findings of current study reveal that by pinching practice the number of branches per plant increased and thereby increased the number of leaves in pinched plants as compared to control. Increase in number of leaves per plant as a result of pinching has been observed previously in China aster [17], Field bean [16] and Bottle gourd [15]. [18] stated that pinching boosts branch production that in turn increases young leaf production, thus a greater number of leaves is related to the number of branches. In their study, they found a greater number of leaves with increasing number of branches in Carnation. Furthermore, the results of the current study also in line with the findings of [19] who reported that pinching treatment resulted more branches in Butternuts, that in turn increased young leaf production.

\section{Number of days to flowering}

The mean values for number of days to flowering are given in table-1 Mean table indicates that different pinching stages showed significant effect on number of days to flowering in different varieties. However, their interaction was found non-significant. According to means for different pinching stages, less number of days to $1^{\text {st }}$ flowering (47.25) was taken by un-pinched plants (control) followed by plants pinched at $3^{\text {rd }}$ node stage (48.17), while maximum days to flowering (50.00) was taken by plants pinched at $1^{\text {st }}$ node stage. Regarding okra varieties, a smaller number of days to $1^{\text {st }}$ flowering (47.42) was noticed in Salva Hybrid followed by Sabz Pari (47.75), whereas a greater number of days to flowering (50.42) was noticed in Arka Anamica. In current study delayed flowering was observed in pinched plants, this might be due to the removal of apical portion. By removing the apical bud, the source of IAA is removed. Since the indole acetic acid is much lower in concentration, and the lateral branches initiation take place and they required more time to mature enough to initiate flowering. Delayed flowering as a result of pinching practice has been reported previously in many crop species including Fenugreek [3] and Bottle gourd [15].

Difference in number of days to flowering in okra varieties might be due to variation in their genotype and their more adoptability to environmental conditions. Similar variations in flowering time among different okra varieties have been reported by $[12,20]$.

\section{Number of pickings}

The mean values for number of pickings are given in table-1. Mean table indicates that different pinching stages significantly affected number of pickings of tested varieties, whereas their interaction was found non-significant. According to means for different pinching stages, a greater number of pickings (23.08) was found in plants pinched at $3^{\text {rd }}$ node stage followed by plants pinched at $2^{\text {nd }}$ node stage (22.33), while minimum number of pickings (20.33) was found in plants which were not pinched. Regarding okra varieties more number of pickings (22.08) was found in Swat Green followed (21.92) by Arka Anamika and Sabz Pari, while less number of pickings (21.25) was observed in Salwa Hybrid variety. In pinched plants the production was knock off for some time but it gave more spread to canopy and bearing age and that may be the reason that maximum number of pickings was observed in plants pinched at $3^{\text {rd }}$ node stage. Similarly, [21] observed more number of pickings and prolonged fruiting in pinched okra plants as compared to un-pinched plants. Maximum number of pickings (22.08) was recorded in Swat Green variety, while minimum number of pickings (21.25) was noticed in Salva Hybrid. The results are also in similarity with the results of [22] who recorded variations in number of pickings in various okra cultivars. Variations in number of pickings might be due to adoptability to the environmental 
conditions or genetic features in different varieties.

\section{Number of pods plant ${ }^{-1}$}

Mean values regarding number of pods plant ${ }^{-}$

${ }^{1}$ are presented in (Table 1). Results reveal that pinching treatment showed significant effect on number of pods plant ${ }^{-1}$, while their interaction was non-significant. As far as the mean values are concerned for different pinching stages, more number of pods per plant (15.53) was observed in plants pinched at $3^{\text {rd }}$ node stage, followed by the plants pinched at $2^{\text {nd }}$ node stage (14.56), whereas less number of pods per plant (13.64) was observed in plants remained un-pinched. The mean values regarding number of pods plant ${ }^{-1}$ in different okra varieties showed that more number of pods per plant (16.38) was recorded in Swat Green followed by Sabz pari (15.30), whereas less number of pods plant $^{-1}$ (13.28) was recorded in Arka Anamica. In this study, more numbers of pods were observed in pinched plants as compared to un- pinched plants. Plants having more number of lateral branches have vigorous vegetative growth, which in turn have good photosynthetic efficiency [23] and have greater translocation of photosynthates from source to sink which in turn have beneficial effects on reproductive growth [24]. Similar to the findings of this study beneficial effect of pinching on reproductive growth has been observed in Butternuts [23], Sunhemp [24], Fenugreek [3] and in Pigeon pea [25]. Our results are also in line with the findings of [26] who reported more number of pods in Fenugreek plants pinched at later stage as compared to earlier stage.

\section{Individual pod weight (g)}

The mean values for individual pod weight are shown in (Table 1). The results reveal significant effect of different pinching stages in tested okra varieties, whereas their interaction was found non-significant. As for as mean values for pinching is concern the highest individual pod weight $(16.03 \mathrm{~g})$ was observed in plants which were pinched at $3^{\text {rd }}$ node stage followed by $(14.64 \mathrm{~g})$ pinched at $2^{\text {nd }}$ node stage, while the lowest individual pod weight $(13.77 \mathrm{~g})$ was observed in unpinched plants. Among okra varieties highest individual pod weight $(15.62 \mathrm{~g}$ ) was recorded in Swat Green followed by (14.84 g) Salva Hybrid, whereas the lowest individual pod weight (13.85 g) was recorded in Sabz Pari. The weight differences could be because of pinching and availability of nutrients. Due to more vegetative growth (branches and leaves) nutrients availability to sink increases which lead to increase in size as well as weight of reproductive growth. Our results are also in agreement with the results of [3] who reported higher pod weight in pinched fenugreek plants. Similar to our results beneficial effect of pinching on individual fruit weight has been reported in various plant species including Butternuts [26], Fenugreek [27] as well as in okra [27].

\section{Pod length $(\mathbf{c m})$}

Mean values for pod length are presented in (Table 1). Mean table showed a significant variation in pod length as affected by pinching stages in different okra varieties; however, their interaction was found nonsignificant. According to means for different pinching stages maximum pod length (12.37 $\mathrm{cm}$ ) was found in plants pinched at $3^{\text {rd }}$ nod stage which is followed by $(11.35 \mathrm{~cm})$ plants pinched at $2^{\text {nd }}$ node stage, whereas minimum pod length $(10.90 \mathrm{~cm})$ was recorded in plants which remained un- pinched. According to the mean values of different varieties of okra maximum pod length $(12.36 \mathrm{~cm})$ was recorded in variety Swat Green, followed by $(11.33 \mathrm{~cm})$ Salwa Hybrid, whereas minimum pod length $(10.99 \mathrm{~cm})$ was recorded in Sabz Pari.

Beneficial effects of pinching on pod size might be related to production and translocation of nutrients from source to sink. Due to more number of leaves the photosynthate especially carbohydrates 
translocate to sink which in turn produces lengthy pods [28]. Previously pinching practice proved beneficial to produce lengthy reproductive parts in several vegetable crop species including Bottle gourd [15] and Fenugreek [26] The difference in pod length in different okra varieties might be due to the genetic makeup of different okra varieties. Same findings were presented by [29-31] who observed significant differences in pod length of different okra varieties.

Table 1. Plant height (cm), Number of Leaves plant ${ }^{-1}$, Number of Branches Plant ${ }^{-1}$, Days to flowering, Number of picking, Pods plant ${ }^{-1}$

\begin{tabular}{|c|c|c|c|c|c|c|}
\hline Factor levels & $\begin{array}{c}\text { Plant } \\
\text { height }(\mathbf{c m})\end{array}$ & $\begin{array}{c}\text { Number of } \\
\text { Leaves plant }^{-1}\end{array}$ & $\begin{array}{c}\text { Number of } \\
\text { Branches Plant }^{-1} \\
\end{array}$ & $\begin{array}{c}\text { Days to } \\
\text { flowering }\end{array}$ & $\begin{array}{l}\text { Number } \\
\text { of picking }\end{array}$ & $\begin{array}{l}\text { Pods } \\
\text { plant }^{-1}\end{array}$ \\
\hline \multicolumn{7}{|c|}{ pinching stages } \\
\hline Control & $137.42 \mathrm{a}$ & $130.50 \mathrm{~b}$ & $6.67 \mathrm{~b}$ & $47.25 \mathrm{c}$ & $20.33 b$ & $13.31 \mathrm{~b}$ \\
\hline P1 & $109.58 b$ & $155.33 \mathrm{ab}$ & $7.57 \mathrm{ab}$ & $50.00 \mathrm{a}$ & $21.42 \mathrm{ab}$ & $13.56 \mathrm{~b}$ \\
\hline $\mathbf{P 2}$ & $114.83 \mathrm{~b}$ & $170.25 \mathrm{a}$ & $8.05 \mathrm{a}$ & $49.25 \mathrm{ab}$ & $22.33 \mathrm{a}$ & $14.56 \mathrm{ab}$ \\
\hline P3 & $116.08 b$ & $176.75 \mathrm{a}$ & $8.15 \mathrm{a}$ & $48.17 \mathrm{bc}$ & $23.08 \mathrm{a}$ & $15.53 \mathrm{a}$ \\
\hline $\mathbf{L S D}(\mathbf{P} \leq \mathbf{0 . 0 5})$ & 18.44 & 32.67 & 0.94 & 1.70 & 1.99 & 1.57 \\
\hline \multicolumn{7}{|l|}{ Varieties } \\
\hline $\begin{array}{c}\text { Arka } \\
\text { Anamika }\end{array}$ & $119.42 \mathrm{a}$ & $142.58 b$ & $7.24 b$ & $50.42 \mathrm{a}$ & $21.92 \mathrm{a}$ & $13.69 b$ \\
\hline Sabz Pari & $125.00 \mathrm{a}$ & $141.00 \mathrm{~b}$ & $6.59 b$ & $47.75 b$ & $21.92 \mathrm{a}$ & $13.47 \mathrm{~b}$ \\
\hline Swat green & $128.33 \mathrm{a}$ & $189.50 \mathrm{a}$ & $8.99 \mathrm{a}$ & $49.08 \mathrm{ab}$ & $22.08 \mathrm{a}$ & $15.17 \mathrm{a}$ \\
\hline $\begin{array}{c}\text { Salwa } \\
\text { hybrid }\end{array}$ & $105.17 \mathrm{a}$ & $159.75 b$ & $7.62 b$ & $47.42 b$ & $21.25 b$ & $14.63 \mathrm{ab}$ \\
\hline $\operatorname{LSD}(P \leq 0.05)$ & 82.25 & 25.28 & 1.27 & 1.94 & 0.57 & 1.25 \\
\hline
\end{tabular}

P1: Pinching at $1^{\text {st }}$ node stage P2: Pinching at $2^{\text {nd }}$ node stage P3: Pinching at $3^{\text {rd }}$ node stage

\section{Pod diameter (mm)}

The mean data for okra pod diameter is shown in (Table 2). According to the results pinching significantly affected the pod diameter in all tested varieties, while their interaction was found non-significant. According to the results of mean values of different pinching stages the maximum pod diameter $(15.18 \mathrm{~mm})$ was found in plants pinched at $3^{\text {rd }}$ node stage followed by $(14.90$ $\mathrm{mm})$ plants pinched at $1^{\text {st }}$ node stage, whereas lowest pod diameter (13.63 $\mathrm{mm})$ was observed in un- pinched plants. According to the mean values of different okra varieties, the thickest pod diameter $(16.52 \mathrm{~mm})$ was found in Swat Green, followed by (15.31 $\mathrm{mm})$ Salva Hybrid, whereas tiniest pods were harvested from $(12.41 \mathrm{~mm})$ Arka Anamika. Increase in pod diameter might be due to the reason of more branches, leaves and availability of more photosynthates from source to sink. [32] stated that as a result of pinching practice hormones and nutrients become balanced, and therefore give higher size of fruits. Similar results were found by [3] in a study on Fenugreek. Further, [27] also determined that fruits retained after pinching give more fruit girth in okra.

The difference in diameter of pods among varieties of Okra might be due to the genetic characteristics of okra cultivars. The same results were observed by [20] who reported significant variation in pod diameter of various varieties of okra.

\section{Plant height (cm)}

The mean values for plant height are given in (Table 2). Mean table indicates that pinching treatment showed significant effect on plant height in all tested varieties while their interaction was found non-significant. 
According to means for different pinching stages, highest plant height $(137.42 \mathrm{~cm})$ was found in un-pinched plants followed by $(116.08 \mathrm{~cm})$ plants pinched at $3^{\text {rd }}$ node stag while minimum plant height $(109.58 \mathrm{~cm})$ was found in plants pinched at $1^{\text {st }}$ node stage. Regarding okra varieties highest plant height $(128.33 \mathrm{~cm})$ was found in Swat Green followed by Sabz Pari $(125.00 \mathrm{~cm})$ while minimum plant height $(105.17 \mathrm{~cm})$ was observed in Salwa Hybrid variety. Plants height is affected by pinching, as auxin (hormone responsible for cell elongation) produced by plants in apical parts is removed and redirected to buds as a result lateral branches are produced and thus causes the reduction in plant height. Similar results were previously reported in Stevia [16] and in Field bean [17]. [18] reported that pinching practice in Carnation promoted lateral branches while reduced plant height. According to [33] removal of apical bud restricts the vertical growth of plant, and converts the photosynthates towards axils of leaves; as a result, more number of lateral branches occurs.

\section{Weight of pods plot ${ }^{-1}(\mathbf{k g})$}

Data regarding weight of pods per plot are shown in (Table 2). The results showed significant effect of pinching stages on weight of pods per picking per plot in all tested varieties, whereas the interaction was found non-significant. Plants pinched at $3^{\text {rd }}$ node stage gave maximum weight of pods $(2.32 \mathrm{~kg})$ per picking per plot, followed by $(2.11 \mathrm{~kg})$ plants pinched at $2^{\text {nd }}$ node, while less weight $(1.82 \mathrm{~kg})$ of pods per picking per plot was observed in un-pinched plants. In case of varieties Swat Green produced more weighted pods $(2.30 \mathrm{~kg})$ per picking per plot, followed by $(2.15 \mathrm{~kg})$ Salwa Hybrid, whereas, less weight of pods $(1.82 \mathrm{~kg})$ per plot was observed in Arka Anamica. Best result of various Okra varieties in weight of fruit per plot might be the genetic makeup high competence of some okra varieties for photosynthesis and respiration rate. Same results were reported by $[34,35]$. [36] reported that in pinched plants the lateral branches are more, having more number of leaves and greater photosynthate formation. Thus the source and sink theory might be the reason of weighted pods in pinched plants. Similar results was observed by [37] who stated that due to pinching practice more photosynthates accumulates to sink that is beneficial for production of weighted pea pods. Similarly pinching has been documented as a beneficial practice to improve yield parameters in Chickpea [14, 38], Cowpea [39] and Pigeonpea [40].

\section{Yield ha-1 (tons)}

The statistical data of yield hectare ${ }^{-1}$ are presented in (Table 2). The results showed that yield $\mathrm{ha}^{-1}$ was significantly affected by pinching in all tested varieties of okra, while the interaction of pinching stages and varieties for yield hectare ${ }^{-1}$ was nonsignificant. The highest yield per hectare (19.39 tons) was observed when pinching was done at $3^{\text {rd }}$ node stage, which is followed by (17.64 tons) pinching done at $2^{\text {nd }}$ node stage, while the minimum yield per hectare (15.16 tons) was observed in plants which were remained un-pinched. Among the tested okra varieties maximum yield per hectare (19.22 tons) was noticed in Swat Green variety, followed by Salwa Hybrid (17.97 tons), whereas, minimum yield (15.18 tons) was recorded in variety Arka Anamica. The yield differences are due to the effect of pinching and availability of nutrients. One of the reasons could be the vigorous vegetative growth (branches and leaves) and greater photosynthate formation in pinched plants. [29] demonstrated that pinching breaks apical dominance and diverts energy towards the production of more branches and results more yield. Previously pinching practice has been reported beneficial for improvement of yield traits in a number of crop species including Fenugreek [26], Bottle guard [41] 
and Field Beans [16]. Differences in yield among different Okra varieties might be due to genetic makeup and adoptability. Similar variations in yield among different cultivars of okra have been reported previously by [3436].

Table 2. Single pod weight $(\mathrm{g})$, pod length $(\mathrm{cm})$, Pod Diameter $(\mathrm{mm})$, Weight of fruits plot ${ }^{-1}$ (kg), Yield ha'-1 (tons)

\begin{tabular}{|c|c|c|c|c|c|}
\hline Factor levels & $\begin{array}{l}\text { Single pod } \\
\text { weight }(g)\end{array}$ & Pod length $(\mathrm{cm})$ & $\begin{array}{c}\text { Pod Diameter } \\
(\mathbf{m m})\end{array}$ & $\begin{array}{l}\text { Weight of fruits } \\
\text { plot }^{-1}(\mathbf{k g})\end{array}$ & $\begin{array}{c}\text { Yield ha }^{-1} \\
\text { (tons) }\end{array}$ \\
\hline \multicolumn{6}{|c|}{ Pinching stages } \\
\hline Control & $13.61 \mathrm{~b}$ & $10.90 \mathrm{~b}$ & $13.63 \mathrm{~b}$ & $1.02 \mathrm{c}$ & $8.51 \mathrm{c}$ \\
\hline P1 & $13.76 \mathrm{~b}$ & $10.99 \mathrm{~b}$ & $14.90 \mathrm{a}$ & $1.14 \mathrm{bc}$ & $9.49 \mathrm{bc}$ \\
\hline $\mathbf{P 2}$ & $14.56 \mathrm{ab}$ & $11.35 \mathrm{ab}$ & $14.85 \mathrm{a}$ & $1.34 \mathrm{ab}$ & $11.13 \mathrm{ab}$ \\
\hline P3 & $14.95 \mathrm{a}$ & $12.37 \mathrm{a}$ & $15.18 \mathrm{a}$ & $1.44 \mathrm{a}$ & $12.02 \mathrm{a}$ \\
\hline $\operatorname{LSD}(P \leq 0.05)$ & 0.96 & 1.04 & 1.13 & 0.29 & 2.44 \\
\hline \multicolumn{6}{|l|}{ Varieties } \\
\hline ArkaAnamika & $13.32 b$ & $10.94 \mathrm{~b}$ & $12.41 \mathrm{bc}$ & $1.19 \mathrm{~b}$ & $9.93 b$ \\
\hline Sabz Pari & $13.68 \mathrm{~b}$ & $10.99 \mathrm{~b}$ & $14.32 \mathrm{c}$ & $1.14 b$ & $9.46 \mathrm{~b}$ \\
\hline Swat green & $15.20 \mathrm{a}$ & $12.36 \mathrm{a}$ & $16.52 \mathrm{a}$ & $1.37 \mathrm{a}$ & $11.44 \mathrm{a}$ \\
\hline Salwa hybrid & $14.67 \mathrm{ab}$ & $11.33 \mathrm{~b}$ & $15.31 \mathrm{ab}$ & $1.24 \mathrm{ab}$ & $10.33 \mathrm{ab}$ \\
\hline $\operatorname{LSD}(P \leq 0.05)$ & 1.36 & 0.89 & 2.09 & 0.15 & 1.28 \\
\hline
\end{tabular}

P1: Pinching at $1^{\text {st }}$ node stage P2: Pinching at $2^{\text {nd }}$ node stage P3: Pinching at $3^{\text {rd }}$ node stage

\section{Conclusion and Recommendations}

Pinching treatment is effective practice to improve growth and yield of okra crop. Among the pinching stages, pinching at $3^{\text {rd }}$ node stage was effective to increase the number of lateral branches plant ${ }^{-1}$, number of leaves plant ${ }^{-1}$, number of pods plant ${ }^{-1}$, pod diameter $(\mathrm{mm})$, individual pod weight $(\mathrm{g})$, number of pickings, yield plot $^{-1}(\mathrm{~kg})$, and yield hectare ${ }^{-1}(\mathrm{~kg})$ of okra varieties. Among the tested okra varieties Swat Green pinched at $3^{\text {rd }}$ node stage produced maximum number of lateral branches plant ${ }^{-1}$, number of leaves plant $^{-1}$, number of pickings, number of pods plant $^{-1}$, pod length $(\mathrm{cm})$, pod diameter $(\mathrm{mm})$, individual pod weight $(\mathrm{g})$, yield $\operatorname{plot}^{-1}(\mathrm{~kg})$, and yield hectare ${ }^{-1}(\mathrm{~kg})$ of okra. It may be recommended that that okra variety, Swat Green may be pinched at $3^{\text {rd }}$ node stage for getting better growth and yield under the Agro-climatic conditions of Dargai Malakand, however, further study is required for the evaluation of different pinching stages in different varieties of okra.

\section{Authors' contributions}

Conceived and designed the experiments: A Ali, G Nabi \& M Irshad, Performed the experiments: A Ali, M Irshad \& MN Khan \& Analyzed the data: $M$ Israr \& S Ali, Contributed reagents/ materials/ analysis tools: J Rehman \& W Ali, Wrote the paper: MN Khan \& M Irshad

\section{References}

1. Khan IA \& Akbar (2015). Population dynamic of natural enemies Ladybird beetle Coccinella septumpunctata L. (Coccinellidae: Coleo[tera) and syrphid fly Episyrphus balteatus Degeer (syrphidea: dipteral) On six okra cultivars in Peshawar. J Ento Zoology Stu 3(5): 24-26.

2. Khan MA, Khan FA, Samiullah, Ijaz U, Ali A \& Nawaz S (2013). Genetic studies for Quality and Nutrient uptake in Okra under irrigated and wastewater. Inter J Agric Crop Sci 744-749.

3. Vasudevan SN, Sudarshan JS, MB Kurdikeri, \& Dharmatu RP (2010). Influence of apical bud pinching, chemicals spray and physiological maturity on seed 
yield and quality of fenugreek. Karnataka. J Agr Sci 21(1): 26-29.

4. Singh AK, Kumar P, Kumar A \& Sisodia A (2014). Effect of pinching, urea and GA. $J$ Orn Hort 17 (2): 38-42.

5. Zeven AC \& Zhukovsky PM (1975). Dictionary of cultivated plants and their centres of Diversity. Centre for Agricultural publishing and Documentation Wageningen The Netherlands pp. 210.

6. Asadipour A \& Madani H (2014). The effects of irrigation and sowing date on the quantitative traits of okra (Abelmoschus esculentus L.). Int J Far All Sci 3 (5): 497501.

7. Arapitsas P (2008). Identification and quantification of polyphenolic compounds from Okra seeds and skins. Food Chem 110: 1041-1045.

8. Saifillah M, \& Rabbani MG (2009). Evaluation and characterization of Okra (Abelmoschus esculentus L. Moench.) genotypes. SAARC J Agric 7: 92-99.

9. Amjad M, Sultan M, Anjum MA, Ayyub CM \& Mushtaq M (2001). Comparative study on the performance of some exotic Okra cultivars. Int J Agri Biol 3: 423-425.

10. Gulsen O, Kargul S \& Akbar K (2007). Diversity and relationships among Turkish Okra germplasm by SRAP and phenolic marker polymorphism. Biologia Bratislava 62: 41-45.

11. MNFSR (2014-2015). Department of Agriculture Statistics govt of Khyber Pakhtunkhwa. pp. 11-18.

12. Khan H, Khan M, Asmatulla, Rasul K, Bahtti A \& Khan M (2000). Response of different cultivars of okra (Abelmoschus esculentus) to three different sowing dates in the mid hill of swat valley. Pak J Biol Sci 3(12): 2010-2012.

13. Sailaja SM \& Panchbhai DM (2014). Effect of pinching on growth and quality characters of China aster varieties. Asian J Hort 9(1): 36-39.

14. Baloch SM \& zubair M (2010). Effect of nippinhy on growth and yield of chickpea. J Anim Pl Sci 20(3): 208-210.
15. Patel AN, Parmar KV Nayak RS \& Patel $\mathrm{MN}$ (2017). Influence of pinching and plant growth regulators on morphological and sex expression of bottle gourd (Lagenaria siceraria L.). Int J C S 5(4): 2035-2038.

16. Kumar ES, Channaveerswami AS Merwade MN, Naik VR \& Krishna A (2018). Influence of Nipping and Hormonal Sprays on Growth and Seed Yield in Field Bean (Lablab purpureus L.) Genotypes. Int J Economic Plants 5(1): 008-014.

17. Kumar R, Sharma S \& Sharma M (2014). Growth and yield of natural-sweetener plant stevia as affected by pinching. Ind $J$ Plant Physiol 19(2): 119-126.

18. Kumar R \& Singh K (2003). Effect of growth regulator and shoot tip pinching on carnation. J Ornt Hort 6(2): 134-136.

19. Eve B, Tuarira M, Moses M \& Thomas M 2016. The influence of pinching on the growth, flowering pattern and yield of butternuts (cucurbita moschata). Int J Hort Orn Plants 2(1): 20-26.

20. Dash PK, Rabbani MG \& Mondal MF (2013). Effect of variety and planting date on the growth and yield of okra. Int J Biosci 3(9): 123-131.

21. Abduljabbar IA, Marie, Ihsan \& Salih S.H (2007). Effect of sowing date, topping and some growth regulators on growth, pod and seeds yield of Okra (Abelmoschus esculentus L.). African Crop Sci Conf Proc 8: 473-478.

22. Hussain S, Sajid M, Amin N, Alam S \& Iqbal Z (2006). Response of okra (Abelmoschus esculentus) cultivars to different sowing times. J Agri Biol Sci 1(1): 55-59.

23. Aikins AK Najombu T \& Msibi ST (2017). Effect of apical pinching on the performance of (Asontem) okra. World $J$ Agr Sci 13(2): 68-74.

24. Dhedhi K, Patoliya K Asha BV, Detroja C, Sorathiya SJ \& Khanpara DM (2017). Effect of pinching and foliar application of nutrients on seed yield and quality of sunhemp (crotalaria Juncea L.) an Int Quarterly J Life Sci 12(2): 1069-1073. 
25. Sharma AP, Potdar M, Pujari TB, Dharmaraj SP (2003). Studies on response of pigeonpea to canopy modification and plant geometry. Karnataka. J Agr Res 16(1): 1-3.

26. Sowmya PT, Naruka IS, Shktawat RPS \& Kushwah SS (2017). Effect of sowing dates and stage of pinching on growth, yield and quality of fenugreek (Trigonella foenum-graecum L). Int J Biol-Resource \& Stress Management 8(1): 91-95.

27. Sajjan AS, Shekhargouda M, Badanur PV (2002). Influence of apical pinching and fruit picking on growth and seed yield of okra. Karnataka. J Agric Sci 15(2): 367372.

28. Kauser H, Bhoomika RH \& Ibaad HM (2016). Effect of sowing dates and stage pinching on growth, seed yield and quality of fenugreek (Trigonella foenum-graecum L.). Res Environ Life Sci 9(9): 1076-1078.

29. Naheed Z, Ayaz A, Rahman A, Khan NA, Ahmad SQ, Hamid FS, Waheed A, Asghar S \& Khan MS (2013). Agronomic traits of okra cultivars under agro-climatic conditions of Baffa (KPK) Pak J Mater Environ Sci 4(5): 655-662.

30. Rahman K, Waseem K, Kashif M, Jilani MS, Kiran M, Ghazunfirrullah \& MamoonUr-Rashid M (2012). Performance of different okra (Abelmoschus esculentus L.) cultivars under the agro-climatic conditions of Dera Ismail khan. Pak J Sci 64(4): 224228.

31. Akram AM \& Shah H (2002). Performance of okra (Abelmoschus esculentus L.) varieties in the up lands of Balochistan (Pakistan). Baloch. J Agric Sci Pak 3(1): 13

32. Shah H, Umaira, Kamran S, Gohar S, Imran A, Gulshan A. Uzma A, Bibi Z. (2019). Conseqenses of sowing dates and umbel pinching on Daucas carota seed production. Pure Appl Biol 8(2): 17711781.

33. Menon R \& Khader AM (1997). Effect of leaf plucking on the growth and grain yield of coriander. Ind. Cocoa. Arecanut \& Spices J 21. 74-75.

34. Ali MB, Lakun HI, Sani SM \& Adamu HM (2014). Effect of organic manure and sowing date on the growth and yield of okra (Abelmoschus esculentus L.) in Samaru, Zaria, Nigeria. Int J Agro Agri Res 5(5): 111-117.

35. Naz I, Khan H, Ali A, Ahmad M, Hussain A \& Tahir M (2009). Effect of various sowing dates and cultivars of the management of okra root rot under natural field conditions. Sarh J Agric 25 (2): 251260.

36. Ahmad A, Abdur R, Muhammad S, Zahid A \& Kawsar A (2016). Influence of pinching intensity and incremental nitrogen application on growth and yield of okra (Abelmoschus esculentus L.) Int J Agric Inviron Res 2(1): 77-85.

37. Singh MS, Devi SK (2006). Profitability of nipping in cultivation of pea (Pisum sativum) an indigenous agro-technique in Manipur. Indian J Agric 51(3): 206-208.

38. Khan HA, Latif S, Mahmood SS, Khan M (2006). Effect of nipping at various stages on yield and yield components of chickpea (Cicer aeritinum L.). J Res Sci 17(4): 235240.

39. Reddy P (2005). Effect of growth retardants and nipping on growth and yield parameters in cowpea (Vigna unguiculata L.). M.Sc. (Agri.) Thesis University of Agricultural Sciences Dharwad Karnataka India.

40. Srinivasan GR, Gobi, Balasubramanian A \& Sathlyamurth S (2019). Influence of nipping and nutrient management practices on growth, yield attributes and yield in pigeon pea. Plant Arch 19(1): 737-740.

41. Anand M, Rohini N, \& Sadasakthi A (2014). Influence of training and pinching on growth, flowering and physiological characters in bottle gourd cv. CBgH1. Trends in Biosci 7(17): 2524-2527. 